\title{
Internationalizing A Business School Program: A Descriptive Study Of A Strategic Implementation Process Of Internationalization
}

\author{
Kathryn T. Cort, (E-mail: kcort@elon.edu), Elon University \\ Jayoti Das, (Email: dastina@elon.edu), Elon University \\ Wonhi J. Synn, (Email: synnwo@elon.edu), Elon University
}

\begin{abstract}
The purpose of this study is to explain the process that a small private business school with limited resources and no prior experience took to internationalize its business school program. The extent of this globalization project was not limited to just revising, initiating, and enhancing its course offerings for accounting, business administration and economics major but it also included a plan to provide additional Study Abroad opportunities for its business students, to develop collaborative partnerships with the Spanish foreign language faculty, and to increase educational programs to the outside business communities. All of these will be briefly explained because this globalization process would be incomplete without their inclusion; however, the focus of this particular study will concentrate on the internationalization of the business school curriculum.
\end{abstract}

\subsection{Introduction}

G

lobalization of businesses and business school curricula are not new trends. In addition, they are trends that will not diminish in importance and magnitude. The major reason for this is that the world today is increasingly interdependent. Trade barriers have decreased and trade agreements have increased leading to more world trade and freer movement of capital, labor, technology, products, and services (Harrison, 2000; Aggarwal, 1989). No longer is the United States isolated from world events elsewhere such as geopolitical issues, terrorism, and financial crises. "Even if a firm faces purely domestic product markets, it faces financial markets that are certainly influenced by global forces" (Aggarwal, 1989, p. 59). Advances in computer and telecommunications technologies have contributed to lower transportation and communication costs and the narrowing of absolute physical distances between markets (Toyne, 1992; Kedia, Harveston, and Bhagat, 2001). With this interdependency of countries has come greater domestic and international competition for U.S. businesses. Therefore, international business executives must know how to interact effectively with peoples of different cultures and countries.

Studies have shown that business leaders believe that it is the responsibility of the business schools to educate college students for careers as competent global managers (Nerht, 1987; Ball \& McCullough, 1993; and Webb, Mayer, Pioche, \& Allen, 1999). Unfortunately, only $29.3 \%$ of the employers that Webb et al. (1994) surveyed in their study agreed that business schools were graduating an adequate supply of qualified entry-level international candidates. Research findings (Beamish \& Calof, 1989; Ball \& McCullough, 1993) have suggested that due to business schools' inability to assess international business needs, academia is perceived to be graduating students with less than optimal academic training. Consequently, corporate America has had to train their employees on the basics of internationalized business aspects. Not only has the business community questioned the quality of international business preparation, but academicians have also contended that inadequately educated U.S.

Readers with comments or questions are encouraged to contact the authors via email. 
business students have weakened the competitiveness of U. S. business (Tung \& Miller, 1990; Ahmed \& Krohn, 1990).

Business schools, as has been stated in past studies (Harrison, 2000; Keating \& Byles, 1991; Webb, Mayer, Pioche \& Allen, 1999), are the institutions that will best prepare our students to compete successfully in the global economy. This belief goes back to the 1960s when the Ford and Carnegie Foundations recommended that business schools internationalize their curricula (Fugate \& Jefferson, 2001). The importance of this issue continued with the American Assembly of Collegiate Schools of Business (AACSB). In 1974, the AACSB required that business schools for accreditation purposes address the issue of international business content in their curricula. In 2000, the AACSB revised their curriculum standards to include "ethical and global issues, demographic diversity and the influence of political, social, legal and regulatory, environmental and technological issues (AACSB, 2000, p. 17). The AACSB is now called the Association to Advance Collegiate Schools of Business AACBS International. The name change reflects the organization's philosophical alteration in allowing foreign universities into membership and its desire to be a global educational organization.

Globalization has been conceptualized "as a situation where political borders become increasingly more irrelevant, economic interdependencies are heightened, and national differences due to dissimilarities in societal cultures are central issues of business" (Kedia \& Mukherji, 1999, p. 232). Globalization and internationalization are used interchangeably in this paper.

A brief literature review on the internationalization efforts of business schools curricula is first presented followed by a description of the process and reasons why a small private university undertook internationalizing its business school. Included in this discussion are the results of its curriculum internationalization efforts. Moreover, the authors make recommendations they perceive to be essential for successful planning, designing, and implementing curriculum globalization. The paper closes with a discussion of the future of this specific internationalization effort and the implications and challenges of internationalizing business school curricula.

\subsection{Literature Review}

Conceptual papers and empirical studies have been done in the area of internationalizing business schools. This review will concentrate on the academic research conducted in the area of globalizing business school curricula. Works focusing on addressing study abroad programs, international internships, and faculty/student exchanges are not addressed in this literature review.

Many of the conceptual articles elaborated on the widely accepted Arpan (1993) and Toyne (1992) pyramid model of internationalization for business education. The three stages of business education internationalization are awareness, understanding, and competence. Toyne's goal of awareness is "to insure that all business students are at least aware (1) of the world beyond our shores and borders, (2) that their world--their standard of living and quality of their life--is inextricably connected to, and impacted by, their 'other' world" (1992, p.24). Kedia, Harveston, and Bhagat (2001) defined "international awareness as having a worldview incorporated into the decision making process" (p.14). The consensus is that awareness is the beginning of the internationalization process and the foundation upon which to reach the understanding level in the pyramid model. Understanding is having the knowledge to comprehend the reasons as to why things happen and their implications for conducting business domestically and internationally (Toyne, 1992). Competence requires the functional use of acquired knowledge, skills, and experience within the context of the business world (Kedia \& Cornwell, 1994).

There are a number of strategies in which to achieve the desired level of business school internationalization. These approaches are neither non-inclusive nor non-exclusive. The infusion or the integrative method is one approach. Typically, this is used in achieving the level of awareness. It requires the coverage of the global dimensions in the core business courses (Aggarwal, 1989; Harrison, 2000). Another strategy is to require or recommend that all students take a survey or introductory course in international business. In addition, requiring or recommending a specific international course within each of the functional areas (i.e. marketing, finance, accounting, economics, etc.) and/or requiring or recommending an international course outside the business school 
provides opportunities to achieve a level of understanding of international business (Aggarwal, 1989). Keatings and Byles (1991) and Aggarwal (1989) recommend that the capstone functional area courses and/or the capstone business policy/strategy course cover the global dimensions of business.

Each of these strategies has weaknesses and strengths in terms of faculty resources, flexibility, and meeting AACSB requirements. The integrative approach is the easiest to implement because it does not require hiring new faculty; but the faculty may have to be retrained. This approach has to be coordinated and monitored to insure a quality level of international instruction. Offering specific courses in each functional area adds to more in depth instruction in that particular discipline but may lack synergy for the entire educational experience for students. However, it allows for more flexibility in offering more courses. Requiring a course in international business for all business students allows for cross-functional integration, but faculty may have to be recruited. However, this approach meets AACSB requirements (Aggarwal, 1989). To achieve competency would require qualified faculty with international expertise and connections to overseas programs and student exchanges. This level of internationalization would demand a great deal of resources, commitment, and coordination (Toyne, 1992).

Since 1974, the AACSB has required business schools to address the issue of internationalization in its curriculum. There have been studies done to assess the implementation of the internationalization of the business school curricula. The most recent study conducted in 2000 (Arpan \& Kwok) revealed that significant progress had been made in the internationalization of business schools. The business schools seem to perceive that achieving a level of awareness is necessary but not sufficient and therefore they are advancing to the understanding level. The study showed that the faculty is more internationalized due to traveling, teaching, and/or living abroad. However, only $15 \%$ of the respondents were very satisfied with the level of faculty internationalization (Arpan \& Kwok, 2000, p.16). Arpan and Kwok found that only a minority of the business schools was very satisfied with the level of internationalization of the curricula and faculty although overall there has been an improvement in these areas. Interestingly, these researchers contend that these findings may come from the fact that "globalization in the world is increasing faster than the internationalization of the curricula and faculty, thereby creating a gap between academia and world developments and realities" (Arpan \& Kwok, 2000, p.18).

Kwok, Arpan, and Folks found in their 1994 study that most business schools strived for a level of general awareness rather than a level understanding or expertise. Seventy-four percent of the business schools used the infusion (integrative) method of curriculum internationalization. Greatest infusion was in the area of marketing and the discipline had the greatest number of undergraduate specialized courses. This is consistent with a study conducted by Thanopoulos and Vernon (1987) in which they found that international marketing is taught in 68\% of the undergraduate and $61 \%$ of the masters programs. As to faculty training, Kwok and Folks reported that on average $64 \%$ of the faculties had minimal to no international business education or training. However, this was deemed an improvement from a study conducted five years earlier.

Nehrt (1987) conducted four surveys to assess the AACSB efforts to internationalize the curriculum of the business schools. Of the thirty workshops/seminars that AACSB had conducted to add an international dimension to the major core courses, $83 \%$ of the participants integrated international dimensions and $44 \%$ added a new international course. The AACSB workshops conducted to add a new course in specific disciplines resulted in 57\% of these participants adding a new course and 68\% adding an international dimension into their courses. These results seem to demonstrate that training fosters the advancement of internationalization in the curriculum. However, Nehrt points out that "although a majority of the schools indicated that they had made the decision to include an international dimension in some or all the core courses, this has not necessarily been implemented" (1987, p.86). Nehrt (1987) found that $20 \%$ of the business schools had not attempted internationalization at the undergraduate level. In a 1993 study (Fleming, Shooshtari, and Wallwork), 22\% of the surveyed schools listed in the AACSB Membership Directory had taken either no action or implementation of the internationalization process.

Fleming, Shooshtari, and Wallwork found that "13\% of the schools have developed internationalization strategies without formally recognizing what those strategies are supposed to accomplish" (1993, p.88). This means "more schools have strategies for curriculum internationalization $(81 \%)$ than those having internationalization as 
part of their mission statements $(68 \%)$ " $(1993$, p. 88). Additional data in this particular study seems to suggest a trend toward offering specific international business courses.

In summary, overall there has been an increasing level of internationalizing the curriculum and a desire to reach a higher level of internationalization. However, the satisfaction levels for the basic bachelors programs, the basic masters programs, and the international masters programs were $3.21,3.30$, and 4.22 , respectively, on a scale of $1=$ not at all and $5=$ very satisfied. The only programs rated lower than the basic bachelors programs were the doctoral programs at a rating of 3.17 (Arpan \& Kwok, 2000, p. 14). Clearly, the current level of satisfaction with internationalization is weak at best.

\subsection{Motivations For Internationalization}

There is no universal strategy to use as a template to internationalize a business school. Schools are different in terms of faculty, student populations, resources, missions, locations, and affiliations. We do not suggest that the internationalization process as reported in this paper is the process that all business schools should implement. However, the information should certainly be useful for guidance, reflection, and affirmation.

What was the major motivation for Elon University to internationalize its business school? Preparing students to compete successfully in the global economy was a major driving factor. However, even though the focus of this paper is on international curriculum issues, the extent of the Love School of Business (LSB)'s globalization project was not limited to revising, initiating, and enhancing its course offerings for accounting, business administration, economics majors and the masters of business administration candidates. It also included a master plan to develop collaborative partnerships with the Spanish foreign language faculty, to provide additional study abroad opportunities for its business students, and to increase educational programs to the outside business communities-outreach programs. All of these will be briefly explained because this globalization process would be incomplete without their inclusion. However, the objective of this particular study is to concentrate on the internationalization of the business school curriculum.

Another motivation is the perpetual pedagogical belief at Elon University to be continuously improving upon what we do best and to investigate and implement programs that best serve the Elon University community. The Love School of Business holds these ideals, too. With such a university-wide philosophy, innovations and changes are open to discussion, promoting creativity, thought, and change.

\subsection{Background Information On Elon University And The Martha And Spencer Love School Of Business}

Elon University is a coeducational, residual, church-related university located in Elon, North Carolina. Both the Town of Elon and the adjacent city of Burlington are in the heart of the Piedmont. The fourth largest of the 37 private colleges and universities in North Carolina, Elon University provides a liberal arts education with professional programs in Accounting, Business Administration, Communications, Computer Science, Education, Engineering, Human Services, Journalism, Music, Public Administration, and Medical Technology. The enrollment for Elon University for the academic year of 2002-2003 is 4425 students.

Elon University is well known for its focus on experiential learning and its extraordinary high level of study abroad participation. The university has been a strong advocate of instilling in its students the importance of living and competing in the global community as demonstrated by requiring a global studies course "The Global Experience" for all freshmen, and by providing a multitude of semester and term study abroad opportunities. Over $46 \%$ of Elon University graduates study abroad.

The Martha and Spencer Love School of Business was established in 1985. The school offers undergraduate-level majors in Accounting, Business Administration (concentrations in Management, Marketing, Finance, International Business, and Management Information Systems), Economics and a graduate degree in Business Administration (MBA). The faculty is composed of 32 full time and 8 part time members for the year 2002-2003. 


\subsection{Assessment Of The International Business Needs}

As stated earlier in this paper, one of the major motivations to undertake this internationalization project was to make the students more qualified for careers requiring a global perspective. Developing skills in undergraduates to allow them to compete in the global economy came from discussions with trustees, business leaders, and government officials at all levels---local, state, and national. In addition, visiting campus recruiters from various industries voiced confirming opinions. Internally, the need for internationalization was visible through an increase in student enrollment in international courses, study abroad opportunities, and participation in the Spanish center, El Centro. A survey sent to 2,200 firms within a five-county revealed that firms felt the need to better educate themselves in order to compete in the global environment. These same findings were also reported in focus group interviews with executives (BIE, pp.10-11). Knowing that the business community perceived a tremendous need to be better prepared to compete globally and that $47 \%$ of the LSB graduates obtain positions in North Carolina, the LSB recognized the need to internationalize its undergraduate and graduate business school curricula, to offer outreach programs to the business community, to increase study abroad opportunities, and to coordinate with the Spanish faculty since many of the firms within the designated region are looking to create business ties with Latin America because of NAFTA.

Dr. John Burbridge, dean of the business school, assessed that even though the university had been quite successful in its efforts of internationalization, the LSB needed to enhance and further advance its business school program" (BIE, p.1). A five-year plan was developed for the LSB based upon its comprehensive assessment. This plan called for the following:

- Internationalize the curriculum for all LSB majors-accounting, business administration and economics;

- $\quad$ Expand the Study Abroad opportunities for LSB students;

- $\quad$ Develop a collaborative partnership with the foreign language faculty in order to design the necessary changes in the language and culture courses for LSB students.

- Increase educational programming for the regional business communities. Provide opportunities for students and faculty to interact with regional businesses on international issues. (BIE, p.1)

To acquire the needed resources to accomplish the goal of "Increasing International Understanding and Economic Enterprise at Elon College and in North Carolina", Elon College under the project direction of Dean Burbridge applied to the U.S. Department of Education for the Business and International Education grant. The application was submitted on November 1, 1999 and granted in the spring of 2000. (As part of Elon College's New Century Plan, Elon College was officially changed to Elon University on June 1, 2001.)

\subsection{Internationalizing The Business Curriculum And The Faculty}

Although this article reports the LSB's internationalization efforts within four areas, the focus of this analysis is on the internationalizing process of the business school curriculum. There is a consensus (Keating \& Byles, 1991; Webb et al, 1999; Kedia \& Cornwell, 1994; and Aggarwal, 1989) that internationalization of the business school curriculum has to be started with faculty who is internationalized. The likelihood of faculty being internationally trained in their graduate programs is minimal. Nehrt (1987) found in a study that only $17 \%$ of the doctoral graduates from the 53 largest doctoral programs had any international courses during their masters and doctoral studies.

The Love School of Business did not assess this before it undertook its internationalization project. However, an assessment of this issue in August 2002 revealed that $53 \%$ of the LSB's faculty had at least one graduate level international business and/or international economics course. Fifty-six percent of the marketing, management, management information systems, and international business professors; $25 \%$ of accounting and finance professors; and $75 \%$ of the economics professors have had at least one graduate level international course. Some of the other interesting findings were: 
- $\quad 22 \%$ of the faculty have taught abroad

- $\quad 34 \%$ of the faculty have led a student study abroad program

- $\quad 81 \%$ of the faculty did not participate in study abroad programs as students themselves

- $\quad 41 \%$ of the faculty have lived abroad

- $\quad 91 \%$ of the faculty have traveled abroad

- $\quad 34 \%$ of the faculty have consulted or done other non-academic work abroad

- $\quad 25 \%$ of the faculty have conducted international research abroad

- $\quad 50 \%$ of the faculty belong to an international business association

- $22 \%$ of the faculty have attended academic international conferences in the U.S.

- $\quad 50 \%$ of the faculty have attended academic international conferences abroad

- $\quad 65 \%$ of the faculty have attended international business educational workshops/seminars

- $\quad 97 \%$ of the faculty have neither held a faculty internship with a firm abroad or with an international firm in the U.S.

- $\quad 9 \%$ of the faculty are a native of another country

With the resources from the BIE Grant, Dean Burbridge invited Dr. Ben Kedia, Director of the CIBER at the University of Memphis, to lead a three-day internationalization seminar. The training at this seminar in May 2000 focused on the reasons for internationalizing, the three levels of internationalization, internationalizing course content, implementing syllabi, seeking needed resources, and integrating non-business courses into the business curriculum. In addition, special instruction on how to create a study abroad program was conducted. Faculty representatives from the Spanish Department attended and participated in a discussion of the importance of language in the curriculum. In addition, Myron M. Miller, former Director of Executive Development Programs at Michigan State University presented a paper to the faculty titled, "The Journey of a Global Manager: Preparing the Next Generation for Their Journey." In his presentation, he highlighted the leadership and skill requirements for global management. His experiences in both business and academia helped to clarify what the challenges lied ahead for us to surmount in order to turn out graduates who could compete in the global marketplace.

Such on-campus seminars, conducted in the springs of 2000 and 2001, were the primary means used by the Love School of Business to internationalize its faculty for this project. A total of 32 faculty members participated in these seminars and four faculty continued the internationalization process by attending the CIBER-sponsored international seminars at the University of Memphis.

Four Elon University faculty members were assigned to be on the internationalization curriculum committee. Three were from within the business school and the fourth committee member was from political science. The responsibilities of this committee were to monitor, coordinate, and assess the globalizing efforts of the faculty. The primary task was to review and assess all syllabi submitted to them. The committee looked to answer the following questions: Did the syllabus mention any international goal or objective? Were there any assignments that were international in nature? Were the assignments/activities substantial in conveying important international concepts, issues, or principles? Were the international components of the course easily identifiable in the syllabus?

It was a requirement that prior to revising their syllabi, faculty members had to have attended the three-day internationalization seminar. Compensation was awarded to faculty whose syllabi were approved. The total number of courses that each faculty member could be financially rewarded was three. Another requirement was that these faculty members administer a three-item evaluation instrument at the end of the semester.

\subsection{Evaluation Of The Internationalization Curriculum Efforts}

\subsection{Year 1}

During the fall semester 2000, eight professors representing the disciplinary areas of accounting, finance, management, economics, business communications, and marketing participated in creating syllabi that were to achieve the LSB's principal objective of creating awareness of global issues, concepts, and interconnectedness among their students. Moreover, as stipulated, each professor had to administer the assessment instrument. The 
confidentiality of the results of this survey for each faculty member was honored and only the aggregate results for the participating faculty were reported.

The survey had three questions. The first question pertained to whether the particular course had increased the student's awareness of global-related issues and concepts. The second question asked whether the student's understanding of the interconnectedness of the United States with the global community had deepened. The third question asked the students to cite any assignment or activity in these courses that had helped them in better understanding global issues related to their particular course.

Questions 1 and 2 were five point Likert type items. The respondents could choose among the following choices: strongly agree, agree, neither agree nor disagree, disagree, strongly disagree. For analysis purposes strongly agree $=5$, agree $=4$, neither agree nor disagree $=3$, disagree $=2$, and strongly disagree $=1$. Question 3 was an open-ended item. If students had cited that they had done an assignment or activity in their class, then this question was scored as a 1. If the students had left it blank or stated that they had not done a global-related activity/assignment, then it was coded as a 2 . In the fall semester 2000, faculty members gave a copied version of their surveys to the globalization curriculum evaluation team. In the process of copying the surveys a few of the responses to questions 1 and 2 were deemed unreadable. Therefore, the responses that were not clear to read were left blank and fell into the category of missing.

The survey data of the ten courses taught by the eight professors for the fall semester 2000 are presented in the following tables:

Question 1: This course increased my awareness of global-related issues and concepts.

\begin{tabular}{|l|c|c|}
\hline \multicolumn{1}{|c|}{ Value } & Frequency & Percent \\
\hline SD = & 6 & 2.4 \\
\hline $\mathbf{D}=\mathbf{2}$ & 15 & 5.9 \\
\hline $\mathbf{N}=\mathbf{3}$ & 48 & 19.0 \\
\hline $\mathbf{A}=\mathbf{4}$ & 155 & 61.3 \\
\hline $\mathbf{S A}=\mathbf{5}$ & 21 & 8.3 \\
\hline Missing & 8 & 3.2 \\
\hline Total & 253 & 100.0 \\
\hline
\end{tabular}

Mean $=3.694$. Median $=4.0$. Mode $=4.0$. Standard deviation $=.810$.

Question 2: This course has deepened my understanding of the interrelationship of the United States with the rest of the world.

\begin{tabular}{|l|c|c|}
\hline \multicolumn{1}{|c|}{ Value } & Frequency & Percent \\
\hline SD $=\mathbf{1}$ & 9 & 3.6 \\
\hline $\mathbf{D}=\mathbf{2}$ & 17 & 6.7 \\
\hline $\mathbf{N}=\mathbf{3}$ & 56 & 22.1 \\
\hline $\mathbf{A}=\mathbf{4}$ & 147 & 58.1 \\
\hline $\mathbf{S A}=\mathbf{5}$ & 18 & 7.1 \\
\hline Missing & 6 & 2.4 \\
\hline Total & 253 & 100.0 \\
\hline
\end{tabular}

Mean $=3.599$. Median $=4.0$. Mode $=4.0$. Standard deviation $=.863$

Question 3: List some specific course assignments/activity in your class that helped you better understand global issues pertaining to this particular course.

\begin{tabular}{|l|c|c|}
\hline \multicolumn{1}{|c|}{ Value } & Frequency & Percent \\
\hline Yes = 1 & 216 & 85.4 \\
\hline No $=\mathbf{2}$ & 35 & 13.8 \\
\hline Missing & 2 & 8 \\
\hline Total & 253 & 100.0 \\
\hline
\end{tabular}

Mean $=1.139$. Median $=1.0$. Standard deviation $=.347$. 
As the data in the tables demonstrate, the faculty was successful in achieving an awareness of globalrelated issues and concepts, and an understanding of the interrelationship of the United States with the rest of the world. Furthermore, students overwhelmingly were able to cite specific learning assignments that dealt with global issues.

In spring semester 2001, six faculty members representing marketing, management, economics, and finance took the initiative to revise their syllabi to reflect the objective of achieving global awareness in the curriculum. The following tables show the results of the mandated survey that was administered at the end of the semester:

Question 1: This course increased my awareness of global-related issues and concepts.

\begin{tabular}{|l|c|c|}
\hline \multicolumn{1}{|c|}{ Value } & Frequency & Percent \\
\hline SD = & 2 & 1.4 \\
\hline $\mathbf{D}=\mathbf{2}$ & 0 & 0 \\
\hline $\mathbf{N}=\mathbf{3}$ & 25 & 17.4 \\
\hline $\mathbf{A}=\mathbf{4}$ & 91 & 63.2 \\
\hline $\mathbf{S A}=\mathbf{5}$ & 26 & 18.1 \\
\hline Total & 144 & 100.0 \\
\hline
\end{tabular}

Mean $=3.965$. Median $=4.0$. Mode $=4.0$. Standard deviation $=.694$.

Question 2: This course has deepened my understanding of the interrelationship of the United States with the rest of the world.

\begin{tabular}{|l|c|c|}
\hline \multicolumn{1}{|c|}{ Value } & Frequency & Percent \\
\hline SD = & 0 & 0 \\
\hline $\mathbf{D}=\mathbf{2}$ & 7 & 2.9 \\
\hline $\mathbf{N}=\mathbf{3}$ & 36 & 25.0 \\
\hline $\mathbf{A}=\mathbf{4}$ & 78 & 54.2 \\
\hline $\mathbf{S A}=\mathbf{5}$ & 23 & 16.0 \\
\hline Total & 144 & 100.0 \\
\hline
\end{tabular}

Mean $=3.813$. Median $=4.0$. Mode $=4.0$. Standard deviation $=.757$.

Question 3: List some specific course assignments/activity in your class that helped you better understand global issues pertaining to this particular course.

\begin{tabular}{|l|c|c|}
\hline \multicolumn{1}{|c|}{ Value } & Frequency & Percent \\
\hline Yes = 1 & 129 & 89.6 \\
\hline No= 2 & 15 & 10.4 \\
\hline Total & 144 & 100.0 \\
\hline
\end{tabular}

Mean $=1.104$. Median $=1.000$. Mode $=1.000$. Standard deviation $=.307$.

In summary for the academic year 2000-2001, of the fifteen business school faculty members who attended the 3-day internationalization seminar conducted by our CIBER representative, 11 professors revised their syllabi. These revisions covered 17 courses encompassing the disciplinary areas of accounting, economics, finance, marketing, and management. The majority of the courses revised were undergraduate course offerings. Three of the course revisions were graduate courses.

\subsection{Year 2}

In May of 2001, Dr. Ben Kedia re-visited The Martha and Spencer Love School of Business to conduct another seminar on globalizing the business curriculum. Faculty members who attended in this seminar for the first time were encouraged to partake in the program of revising their syllabi for the academic year 2001-02. In addition, to keep consistency, those faculty members who revised their syllabi were required to administer the 3-item evaluation tool at the end of the semester. For the academic year 2001-02, 17 faculty members participated in the 
May 2001 globalization curriculum seminar. Of those who attended the seminar, 11 faculty members rewrote their syllabi to include the infusion of globalization issues and concepts. This represented a total 13 newly revised course---11 undergraduate courses and 2 graduate courses.

The following tables report the aggregate findings of the 3-item globalization survey for the academic year 2001-2002:

Question 1: This course increased my awareness of global-related issues and concepts.

\begin{tabular}{|l|c|c|}
\hline \multicolumn{1}{|c|}{ Value } & Frequency & \\
\hline SD = 1 & 4 & \\
\hline $\mathbf{D}=\mathbf{2}$ & 31 & .8 \\
\hline $\mathbf{N}=\mathbf{3}$ & 76 & 6.2 \\
\hline $\mathbf{A}=\mathbf{4}$ & 299 & 15.2 \\
\hline $\mathbf{S A}=\mathbf{5}$ & 89 & 59.9 \\
\hline Total & 499 & 17.8 \\
\hline
\end{tabular}

Mean $=3.878$. Median $=4.000$. Mode $=4.0$. Standard deviation $=.79852$.

Question 2: This course has deepened my understanding of the interrelationship of the United States with the rest of the world.

\begin{tabular}{|l|c|c|}
\hline \multicolumn{1}{|c|}{ Value } & Frequency & Percent \\
\hline $\mathbf{S D}=\mathbf{1}$ & 6 & 1.2 \\
\hline $\mathbf{D}=\mathbf{2}$ & 32 & 6.4 \\
\hline $\mathbf{N}=\mathbf{3}$ & 112 & 22.4 \\
\hline $\mathbf{A}=\mathbf{4}$ & 281 & 56.3 \\
\hline $\mathbf{S A}=\mathbf{5}$ & 68 & 13.6 \\
\hline Total & 499 & 100.0 \\
\hline
\end{tabular}

Mean $=3.7475$. Median $=4.000$. Median $=4.00$. Standard deviation $=.81426$.

Question 3: List some specific course assignments/activity in your class that helped you better understand global issues pertaining to this particular course.

\begin{tabular}{|l|c|c|}
\hline \multicolumn{1}{|c|}{ Value } & Frequency & Percent \\
\hline Yes = 1 & 430 & 86.2 \\
\hline No= 2 & 69 & 13.8 \\
\hline Total & 499 & 100.0 \\
\hline
\end{tabular}

Mean $=1.1283$. Median $=1.000$. Mode $=1.00$. Standard deviation $=.34554$

The following table compares the means on the three evaluation questions during the duration of this project:

\begin{tabular}{|l|c|c|c|}
\hline \multicolumn{1}{|c|}{ Semester/year } & $\begin{array}{c}\text { Question \#1 } \\
\text { (Issues) }\end{array}$ & Question \#2 (Understanding) & $\begin{array}{c}\text { Question \#3 } \\
\text { (Activity/Assignment) }\end{array}$ \\
\hline Fall Semester 2000 & 3.694 & 3.599 & 1.139 \\
\hline Spring Semester 2001 & 3.965 & 3.813 & 1.104 \\
\hline AY 2001-2002 & 3.878 & 3.748 & 1.138 \\
\hline
\end{tabular}

Questions 1 and 2 were coded: Strongly Agree=5; Agree=4, Neither Disagree nor Agree=3; Disagree=2; Strongly Disagree=1. Question 3 was coded $\mathrm{Yes}=1 ; \mathrm{No}=2$.

\subsection{Summary And Discussion}

Most of the faculty members infused global concepts and issues within the content of their courses. This is consistent with the overall goal of creating global awareness. The goal was overwhelmingly achieved as witnessed by the three-item survey. 
Upon completion of this two-year project, the curriculum committee conducted content analyses of the responses to the open-end question on the survey that stated, "List some specific course assignment/activity in your class that helped you better understand global issues pertaining to this particular course." The committee crossed these responses to the course syllabus to see whether what the faculty member stated that he/she was going to do actually did get accomplished. Through these content analyses, the results clearly indicated that in $98 \%$ of the courses the objective(s) of the professor matched what the students reported. The students' recalls were very specific in nature. Many of the students in the open-end response question commented on how the entire course was global in its daily approach. Interestingly, many of these courses were not global/ international-titled courses. Statements made to this question also revealed that many students would like more time devoted to the international dimensions of their specific disciplines.

Evaluation of the syllabi was good for the faculty. First, it made some faculty members who had been implicitly integrating international dimensions in their courses to explicitly state those components. This was enlightening for them to see. It also gave them a foundation upon which to infuse additional international content. Second, it started to create an integrative theme within the entire business school curriculum. This is good because it enhances and reinforces cross-functional course goals. Third, it allows for more interdisciplinary discussion among the faculty members.

An outgrowth of all this integration has been an increase in international research among and between faculty members. The BIE Grant was valuable in funding many of the cooperative international research projects. This is significant because this is one of the main approaches to internationalizing the faculty. Every discipline of the business school was represented in the internationalization process---accounting, business administration (marketing, management, finance, international business, management information systems), and economics. Of the core courses required for an undergraduate degree in Business Administration, 61.5\% were internationalized. Fifty percent of the required courses for a Masters in Business Administration were internationalized. During the first year of the BIE Grant, Global Marketing was offered as a pilot course. This course is now a required course for students pursuing the marketing concentration and an elective course within the international business concentration. Specific international courses offered within the School of Business are Global Marketing (Marketing), International Trade and Finance (Economics), Global Financial Markets (Finance), and International Business Management (Management) at the undergraduate level and International Business at the graduate level. In the second year of the BIE Grant, curriculum changes within the Department of Business Administration occurred. All concentrations within this department have added the requirement that every student has to take an upper division course from the Liberal Studies course offerings. Faculty advisors are to assist students in selecting appropriate courses. This will provide the opportunity for students to take a course that will enhance their global awareness and understanding of other cultures, values, and beliefs.

\subsection{Suggested Requirements For Successful Internationalization Of A Business School}

Some salient factors seem necessary for success. A critical element involves top level support and commitment, either at the university level and/or at business school level. Presidents, provosts, deans, department chairs, and other influential decision-makers need to be supportive and committed to this type of project. This support should be financial and/or motivational. Like with corporate America, if the faculty does not perceive that this is a priority with administrators, they are not going to be committed. Financial support from the institution is not necessary if outside funding can be obtained. However, additional funds are necessary for the internationalization of students, faculty, and curriculum.

Although some schools have embarked upon a globalization business school strategy without mission statements and corresponding objectives, it would be most beneficial if schools did this before beginning their internationalization processes. There are few reasons for this. First, this is a good way to communicate commitment. Second, schools can assess their progress in the process based upon these benchmarks.

This process requires a champion or champions. These champions can be deans, department chairs, or coordinators. Not all faculty members have to be champions, but the business school needs in-house faculty who is 
supportive, influential, and respected. The reason is that the internationalization of the curriculum concept will go through a diffusion process among the faculty much like any other product, service, idea, and information that is being marketed to consumers. The champions will act much like opinion leaders in the outside business communities. They can have a tremendous impact on the success and speed of the process.

To help develop and increase the level of faculty internationalization, opportunities for the faculty to attend international seminars, workshops, and courses should be encouraged. It is impossible to be successful in this process if the faculty is internationally deficient within their respective disciplines.

Not only does this process need strategic planning and implementation but it warrants assessment, too. Actually, evaluation of the process should be continuous. The internationalization process objectives, levels of faculty and student internationalization, curriculum changes, and course objectives are items that need monitoring and evaluation.

\subsection{Challenges Of Internationalizing A Business School}

To internationalize a business school means that changes will occur. However, like with most changes, especially within academia, debate and resistance to change are common. The real challenge of change comes with creating a life long commitment to that change. Some business schools may have resistance at the executive university level, especially if the mission of the university or college is not globally oriented and/or lack the resources to implement curricula changes. This probably is not as great of a problem as convincing the faculty who will be in charge of carrying out the globalization goals. Where will this resistance be? It could come from two category of faculty - the inexperienced and seasoned faculty members. Both have reasons to be non-receptive toward change. The neophytes are trying to survive and without proper mentoring, may not have a clue to internationalizing their courses. Moreover, as we know from past empirical studies, many doctoral students are graduating with no general international business course or international course in their disciplines. The veteran faculty members may be set in their ways, which leads to resistance to alter what they have been doing for some time.

Another challenge is consistency. Faculty turnover occurs. These changes can be negative to the internationalization process if the turnover involves the champion(s). However, this problem can be alleviated by delegating responsibilities to others and educating a sufficient number of the faculty to the importance of globalization.

Commitment of the faculty to this cause is another challenge. The question we have to ask ourselves at Elon University is "Will the faculty be as committed to internationalizing their courses if they are not being reimbursed for their efforts?" The BIE Grant provided the necessary funding to compensate the faculty for their efforts. However, that funding has ended. Like with most faculties, unless their efforts are being rewarded, they are not going to assume additional tasks that will not serve them best in seeking tenure and promotion. Therefore, the challenge is how to advance this process forward if there are no rewards in terms of compensation or faculty status. Funding also has a very important role to play in the level of internationalization that a business school chooses. Creating an awareness level does not require as many resources as understanding and certainly not nearly as many resources as are needed to implement a competency strategy.

Another major challenge is coordinating and integrating the internationalization of business schools. As we reported earlier, the Love School of Business process involved four salient components-curriculum, study abroad opportunities, outreach programs, and language. One of the criticisms that Keating and Byles (1991) stated in their article is that students may become more aware of international dimensions but the curriculum may not be "internationalized" because the internationalization approaches are haphazard and not coordinated by the faculty. Business schools should address this issue. At Elon University, we know through our course existing surveys that the Love School of Business did achieve its objective of creating global awareness. We also know that the subjective open-end responses of the students showed a trend toward a coordinated and integrated international curriculum. However, the challenge will be to foster and advance this coordination in the years to come. A more 
demanding challenge within the Love School of Business is how to continue to coordinate and integrate all of the components of the project, especially in lieu of the fact that federal funding has ended.

Many challenges face business schools in their attempts to internationalize their business schools and in particular their curricula. However, we know that American businesses need universities to properly trained and educate business students so that they can compete in the global economy. Unfortunately, unless the business school faculty possesses international knowledge and skills, it cannot adequately impart a global mindset onto their students so that they are competent in the global workplace.

We, at Elon University have many of same challenges to overcome as stated in this paper. However, the Love School of Business is in an exciting time in his history in that it is in its final year of candidacy for AACSB accreditation, planning for the future building of a new Business School facility, and being part of a University that is being publicly applauded for its academic excellence.

\section{References}

1. Aggarwal, R. (1989). "Strategies for Internationalizing the Business School: Educating for the Global Economy." Journal of Marketing Education, 11, pp.59-64.

2. Ahmed, Z.U., \& Krohn, F.B. (1990). Internationalizing business programs at non-AACSB-accredited collegiate institutions. Journal of Education for Business, 66(2), pp. 78-82.

3. Arpan, J.S. (1993). "Internationalizing the business school curricula: The case of the cheshire cat." In S. Tamer \& T. Cavusgil, editors, Internationalizing business education; Meeting the challenge. East Lansing, Mich.: Michigan State University Press.

4. Arpan, J.S., \& Kwok, C.C.Y. (2000), INTERNATIONALIZING THE BUSINESS SCHOOL: Global Survey of Institutions of Higher Learning in the Year 2000. The Academy of International Business and The Center for International Business Education and Research at The Darla Moore School of Business of the University of South Carolina, pp. 1-31.

5. Ball, D.A., \& McCullough, W.H. (1993). "The Views of American Multinational CEOs on Internationalized Business Education for Prospective Employees.” Journal of International Business

6. Beamish, P.W., \& Calof, J.L. (1989). "International Business Education: A Corporate View." Journal of International Business Studies, 20(3), pp. 553-565.

7. BIE Grant proposal, CFDA No 84.153. (1999). Increasing International Understanding and Economic Enterprise at Elon College and in North Carolina, submitted by Elon College to the Department of Education.

8. Fleming, M.J., Shooshtari, N.H., \& Wallwork, S.S. (1993). "Internationalizing the Business Curriculum: A Survey of Collegiate Business Schools.” Journal of Teaching in International Business., 4(2), pp.77-99.

9. Fugate, D.L., \& Jefferson, R.W. (2001). "Preparing for Globalization-Do We Need Structural Change for Our Academic Programs," Journal of Education for Business, 76(3), pp.160-167.

10. Harrison, D. (2000). "The changing face of business education: Challenges for tomorrow." Review of Business, 21(3/4), pp. 43-46.

11. Keating, R., \& Byles, C. M. (1991). "Internationalizing the business school curriculum: Perspectives on successful implementation." Journal of Education for Business, 67(1), pp.2-16.

12. Kedia B.L. \& Cornwell, T.B. (1994). "Mission Based Strategies for Internationalizing U.S. Business Schools.” Journal of Teaching in International Business, 5(3), pp.11-29.

13. Kedia, B.L., Harveston, P.D., \& Bhagat, R.S. (2001). "Orienting Curricula and Teaching to Produce International Managers for Global Competition." Journal of Teaching in International Business, 13(1), pp. 1-22.

14. Kedia, B.L., \& Mukherji, A. (1999). "Global Managers: Developing A Mindset for Global Competitiveness." Journal of World Business, 34(3), pp. 230-251.

15. Kwok, C.C.Y., Arpan, J., \& Folks, Jr., W.R. (1994). "A Global Survey of International Business Education in the 1990s," Journal of International Business Studies, 25(3), pp. 605-623.

16. Nehrt, L.C. (1987). "The Internationalization of the Curriculum.” Journal of International Business Studies, 18(1), pp. 83-90.

17. Thanopoulos,J., \& Vernon, I. (1987). "International Business Education in the AACSB Schools." Journal of International Business Studies, 18(1), pp. 91-98.

18. Toyne, B. (1992). "Internationalizing Business Education.” B\&E Review, pp.23-27.

19. Tung, R. L., \& Miller, E. L. (199). "Managing in the twenty-first century: The need for global orientation." Management International Review, 30(1), pp. 5-18.

20. Webb, M.S., Mayer, K.R., Pioche, V., \& Allen, L.C. (1994). "Internationalization of American Business Education." Management International Review, 39(4), pp. 379-397. 
